Scholarship at Cambridge (1931-32), followed by a Commonwealth Fund Harkness Fellowship (1932-35) at Columbia University. He returned to Cambridge in 1935 as Amy Mary Preston Read fellow and later Royal Society Messel research fellow until 1940. From 1940 to 1944 he investigated the fouling of ships' hulls for the Marine Corrosion Sub-committee of the Iron and Steel Institute, a committee of which he later became chairman.

$\mathrm{He}$ was appointed to the chair of zoology in Bristol in 1944. From then, until his appointment as vice-chancellor twenty-two years later, he was actively engaged in research and in building up the department, which came to be one of the largest in the country, recognized every. where as one of the happiest and most productive. His own researches ranged very widely : they include such diverse interests as hydrodynamies of fish locomotion, vertebrate palaenntology, early movements of the verte. brate embryo, functional morphology of Ascaris, and vertical migration of plankton. The high quality and originality of this work led to his election to the Royal Society in 1956. In 1961 he was appointed a CBE.

But his contribution to science cannot be measured by the list of his publications. Harris knew much more than he ever wrote, and his influence was transmitted more by personal contact than by the printed word. An explan. ation of the growth and extraordinary stability of the Department of Zoology - few ever left it and then almost only for chairs in other universities - is to be found in Harris's integrity and industry, in his courteous ability to further a colleague's work without directing it.

Although Harris won an assured place for himself as a zoologist, it is arguable that he made an even greater contribution to the progress of biology not only by his leadership of the Department of Zoology but also by the leadership and vision to which he gave effect on such bodies as the Advisory Committee on Fisheries (1953-65), the Council of the Royal Society (1960-62), the Agricultural Research Council (from 1962), the Natural Environment Research Council (from 1965), and many others.

In time Harris was drawn more and more into problems of teaching and administration. Long before 1966 when he became vice-chancellor he had become known within the university and far boyond as an administrator who could produce workable schemes. When Sir Philip Morris retired from the vice-chancellorship, John Harris was the obvious choice as his successor, and it can rarely have happened that the obvious choice was so completely acceptable. Even so, his success in the short term of his actual tenure was remarkable. At his appointmont, everyone thought him supremely qualified for the work. It was typical that he himself spoke cheerfully but quite seriously of having to learn a completely new job, and he set about gathering information and mastering the administration with the fine judgment and mental energy that had distinguished all his previous work.

\section{Professor Lieven Ferdinand de Beaufort}

() $N$ May 11 Professor de Beaufort died aged 89 after a short illness. For about 20 years he had enjoyed the life of an emeritus professor at his beautiful country house at Leeusden near Amersfoort where he had continued his scientific pursuits after retirement.

Born on March 23, 1879, at Leusden, the son of the historian and statesman W.H. de Beaufort, he had a great interest in natural history from his early youth. He began his scientific career as an honorary assistant to Professor Max Weber, whom he suceeded in 1922 as director of the Zoological Museum of the University of Amsterdam. In 1926 de Beaufort was appointed a professor of zoogeography and later also of pharmaceutical zoology.

As early as 1902 as a bachelor of science he had taken part in the first Dutch New Guinea Expedition, and from 1909 to 1910 he travelled with his first wife to Waigeu and Ceram to make zoological collections on these interesting islands. He published a report on the birds collected during the first expedition in Nova Guinea and remained a keen ornithologist for the rest of his life, although under the influence of Max Wober his scientific interest soon turned to the study of fishes, especially those of the East Indies. De Beaufort and Max Weber edited seven volumes of The Fishes of the Indo-Australian Archipelago, and de Beaufort continued the work until 195I, when he published the ninth volume in collaboration with W. M. Chapman.

De Beaufort contributed much to our knowledge of fishes and birds. His three handbooks Zoögeographie van den Indischen Archipel (1926), Zoögeographi (1943) and Zoogeography of the Land and Inland Waters (1951) are still extensively used and quoted. After Max Weber's death ho edited the Results of the Siboga Hixpedition.

De Beaufort supervised investigations of the fauna and flora of the Zuiderzee, before and after it was made into a freshwater basin. He served as member and president of many boards and commissions, including the Corrmission for Applied Scientific Research (TNO), the Commission for Scientific Research in the Tropics, the Netherlands Ornithological Society, the Geographical and the Entomological Societies. Since 1928 he had been on the board of the Amsterdam Zoological Gardens.

In appreciation of his work on the fishes of the Indian Ocean, Professor de Beaufort was invited to the Indian Science Congress in 1937. For the same reason he was awarded the Golden Joy Gobind Law Medal for Asiatic Researches in Zoology of the Royal Asiatic Society of Bengal. After organizing the seventh International Ornithological Congress in 1930 he was made Ehrenmitglied des Bundes der Ungarischen Ornithologen and the Ornithologische Gesollschaft in Bayern. In 1938 ho was made a corresponding member of the Zoological Society of London and an honorary foreign silver jubilee member of the Indian Science Congress Association. In 1946 he became an honorary foreign member of the American Society of Ichthyologists and Herpetologists.

\section{Professor N. J. Giarman}

THE news of the sudden and untimely death on October 10 , at the age of 48 , of Dr Nicholas J. Giarman will sadden pharmacologists in many parts of the world. Giarman, professor of pharmacology at the Yale University School of Medicine, was well known to his British colleagues. He had spent a year in the University of Edinburgh during the academic year 1954-55, working in J. H. Gaddum's laboratory; an interesting study of the ability of nervous tissue to synthesize 5-hydroxytryptamine was the outcome of that stay. From then on his interest was centred on neuropharmacology and it was to this field that his own research and that of his colleagues mainly contributed.

For most of his active career Giarman worked at the Pharmacology Department in Yale, where he took his $\mathrm{PhD}$ in 1948. Here he built up a very active research group. For this he was well suited, being well versed in classical and modern methods of pharmacological research, but he was also an outstanding teacher, able to awaken and hold the interest of younger colleagues. It is therefore not surprising that there was a stream of visitors to his laboratory, both from within the United States and from abroad. Some of these have already taken up responsible positions elsewhere. He was also a clear and interesting writer; this gift is woll exemplified in his latest review article, written jointly with F. E. Bloom, on "Physiologic and Pharmacologic Considerations of Biogenic Amines in the Central Nervous System", which appeared earlier this year in volume 8 of the Annual Review of Pharmacology. Giarman was for many years regional editor of Biochernical Pharmacology, an office to which he devoted much time and care. 